\title{
Delphinidin induces cell cycle arrest and apoptosis in HER-2 positive breast cancer cell lines by regulating the NF-kB and MAPK signaling pathways
}

\author{
AILIN WU ${ }^{1,2 *}$, YANFENG ZHU ${ }^{3 *}$, BIN HAN $^{4 *}$, JIAYUAN PENG $^{1}$, XIAOMIN DENG ${ }^{1}$, \\ WEI CHEN ${ }^{1}$, JINGCHANG DU $^{4}$, YU OU ${ }^{5}$, XIAOLI PENG ${ }^{4}$ and XIAOPING YU ${ }^{3}$ \\ ${ }^{1}$ Basic Medical School, Chengdu Medical College, Chengdu, Sichuan 610500; ${ }^{2}$ Ministry of Science and Technology, \\ The Second Affiliated Hospital of Chengdu Medical College, China National Nuclear Corporation 416 Hospital, \\ Chengdu, Sichuan $610051 ;{ }^{3}$ Graduate School; ${ }^{4}$ School of Public Health; \\ ${ }^{5}$ Division of Planning and Finance, Chengdu Medical College, Chengdu, Sichuan 610500, P.R. China
}

Received May 10,2020; Accepted June 25, 2021

DOI: 10.3892/ol.2021.13093

\begin{abstract}
Delphinidin is an anthocyanidin monomer, commonly found in vegetables and fruits, and has demonstrated antitumor effects in the HER-2-positive MDA-MB-453 breast cancer cell line, with low cytotoxicity on normal breast cells. However, the direct functional mechanisms underlying the effect of delphinidin on HER-2-positive breast cancer cells has not been fully characterized. In the present study, it was found that delphinidin could induce $\mathrm{G}_{2} / \mathrm{M}$ phase cell cycle arrest by inhibiting the protein expression level of cyclin B1 and Cdk1 in HER-2-positive breast cancer cell lines. In addition, delphinidin promoted the mitochondrial apoptosis pathway by inhibiting the ERK and NF- $\mathrm{BB}$ signaling pathway and activating the JNK signaling pathway. Therefore, delphinidin markedly suppressed the viability of the HER-2-positive breast cancer cell lines by modulating the cell cycle and inducing apoptosis. Overall, the findings from the present study demonstrated that delphinidin treatment could induce the mitochondrial apoptosis pathway in human HER-2-positive breast cancer cell lines, providing an experimental basis for the prevention and treatment of HER-2-positive breast cancer by flavonoids.
\end{abstract}

Correspondence to: Dr Xiaoli Peng, School of Public Health, Chengdu Medical College, 783 Xindu Avenue, Chengdu, Sichuan 610500, P.R. China

E-mail: xiaopeng967@sohu.com

Dr Xiaoping Yu, Graduate School, Chengdu Medical College, 783 Xindu Avenue, Chengdu, Sichuan 610500, P.R. China

E-mail: yuxp@cmc.edu.cn

*Contributed equally

Key words: delphinidin, HER-2-positive breast cancer, cell cycle arrest, apoptosis, NF- $\kappa \mathrm{B}$ signaling pathway, MAPK signaling pathway

\section{Introduction}

Breast cancer is among the most common type among women worldwide(1). Human epidermal growth factor receptor(HER)-2 is overexpressed in 20-30\% of all breast cancer types (2) and is a preferred target for treating HER-2-positive breast cancer. Trastuzumab and pertuzumab, two HER2-targeted monoclonal antibodies, are used as adjuvant therapy to treat metastatic HER-2-positive breast cancer when combined with docetaxel. However, only a small percentage of patients benefit from this therapeutic method (3). Thus, identifying novel agents or drug combination and developing new therapeutic strategies is urgently required.

Delphinidin is an anthocyanidin monomer commonly found in vegetables and fruits (4). The benefits of delphinidin have been associated with its antioxidant, anti-inflammatory, antiangiogenic and anticancer effects (5). Delphinidin contains 3 hydroxyl groups on its B ring, making its oxidative biological effect stronger compared with that in other flavonoid compounds, such as cyanidin and malvidin (5-7). Delphinidin has the strongest antioxidant effect among all anthocyanidins. It is considered to be the most beneficial anthocyanidin, which has become the focus of anti-cancer research in anthocyanin monomers. Our previous studies confirmed the anticancer activities of anthocyanidin and delphinidin-3-glucoside in breast cancer cell lines. Luo et al (8) used structural biology methods to demonstrate that delphinidin could dock with the HER-2 tyrosine kinase region in the HER-2-positive MDA-MB-453 breast cancer cell line using hydrophobic forces and hydrogen bonding. This inhibited competitive ATP binding to the HER-2 receptor, thus preventing the autophosphorylation of HER-2 and exerting its anti-cancer effect (8-11). In addition, the therapeutic effects of delphinidin in cancer have been associated with the inhibition of MAPK and NF- $\mathrm{BB}$ signaling, and the activation of the AP-1 signaling pathway $(12,13)$. Therefore, the purpose of the current study was to determine the in vitro biological effects of delphinidin in 2 HER-2-positive breast cancer cell lines.

We hypothesized that delphinidin could induce mitochondrial pathway apoptosis by modulating NF- $\mathrm{B}$ and MAPK 
signaling in the HER-2-positive MDA-MB-453 and BT-474 breast cancer cell lines. The results of the present study may indicate that delphinidin is a valuable therapeutic agent for patients with breast cancer. This may provide new insight for the prevention and treatment of HER-2-positive breast cancer using delphinidin.

\section{Materials and methods}

Cell culture and treatment. The HER-2-positive breast cancer cell lines (MDA-MB-453 and BT-474) were purchased from the Chinese Academy of Sciences. The MDA-MB-453 cell line was cultured in L-15 medium (cat. no. 11415-064; Gibco; Thermo Fisher Scientific, Inc.), while the BT-474 cell line was cultured in RPMI-1640 medium (cat. no. A1049101; Gibco; Thermo Fisher Scientific, Inc.) and both supplemented with $10 \%$ fetal bovine serum (cat. no. ES-009-B; EMD Millipore), and at $37^{\circ} \mathrm{C}$ in a humidified incubator with $5 \% \mathrm{CO}_{2}$. Delphinidin (cat. no. 43725; purity $\geq 95 \%$ ) was dissolved in dimethyl sulfoxide (DMSO; cat. no. D2650) (both from Sigma-Aldrich; Merck KGaA) to a stock concentration of $80 \mathrm{mM}$. The DMSO was added to the medium at a final concentration of $0.1 \%$ as a control.

Antibodies and reagents. The anti-rabbit IgG, HRP-linked (cat. no. 7074), anti-mouse IgG, HRP-linked (cat. no. 7076), p21 $1^{\text {Waf1/Cip1 }}$ (cat. no. 2947), c-Raf (cat. no. 53745), phosphorylated(p)-c-Raf (cat. no. 9431), MEK1/2 (cat. no. 9126), p-MEK1/2 (cat. no. 9154), p44/42 MAPK (Erk1/2) (cat. no. 4695), p-p44/42 MAPK (Erk1/2) (cat. no. 4370), SAPK/JNK (cat. no. 252), p-SAPK/JNK (cat. no. 4668), Bax (cat. no. 5023S), Bcl-2 (cat. no. 4223S), PKC $\alpha$ (cat. no. 59754), IKK $\alpha$ (cat. no. 11930), IKK $\beta$ (cat. no. 8943), p-IKK $\alpha / \beta$ (cat.

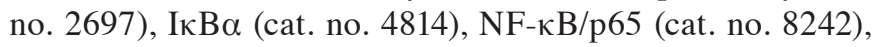
GAPDH (cat. no. 5174) antibodies, and Alexa Fluor 594 conjugate (cat. no. 8889) and Alexa Fluor 488 phalloidin (cat. no. 8878) were purchased from Cell Signaling Technology, Inc. The cyclin B1 (cat. no. ab32053), Cdk1 (cat. no. ab133327), p-PKC $\alpha$ (cat. no. ab23513), p-IкB $\alpha$ (cat. no. ab12134), p-NF- $\kappa$ B/p65 (cat. no. ab131109) antibodies were purchased from Abcam. The $\beta$-actin (cat. no. TA-09) antibody was purchased from OriGene Technologies, Inc.

Cytotoxicity assay. The MDA-MB-453 and BT-474 breast cancer cell lines were seeded in 96-well microtiter plates ( $1 \times 10^{4}$ cells per well), then treated with delphinidin at different concentrations $(10,20,40,80$ and $160 \mu \mathrm{M})$ or treated with the vehicle (DMSO) for 48 h. Cell Counting Kit-8 (CCK-8; cat. no. CK04; Dojindo Molecular Technologies, Inc.) was used to evaluate the viability of the cells. The absorbance was read at $450 \mathrm{~nm}$ using a microplate reader (Powerwave XS; Bio Tek China). Then SPSS v21.0 (IBM Corp.) was used to calculate $\mathrm{IC}_{50}$.

Cellular morphological observation. Approximately $2 \times 10^{5}$ cells were seeded in 6 -well plates, containing glass coverslips. The cells were treated with delphinidin at different concentrations $(20,40$ and $80 \mu \mathrm{M})$ or with DMSO for $48 \mathrm{~h}$. The cells were then fixed using $4 \%$ paraformaldehyde for $20 \mathrm{~min}$ and stained (for 3-5 min with hematoxylin and 1 min with eosin), both at room temperature, according to the instructions of the H\&E staining kit (cat. no. D006; Nanjing Jiancheng Bioengineering Institute). Finally, the cells were observed with a light microscope at x200 magnification.

Cell cycle analysis. Approximately $2 \times 10^{5}$ cells were seeded in 6-well plates, containing glass coverslips. The cells were treated with the delphinidin at different concentrations (20, 40 and $80 \mu \mathrm{M}$ ) or treated with DMSO for $48 \mathrm{~h}$. The cells were then harvested in a culture dish, washed with ice-cold PBS and fixed with $80 \%$ ice-cold ethanol in PBS at $4^{\circ} \mathrm{C}$ for $4 \mathrm{~h}$. The cells were then pelleted in a cool centrifuge $\left(120 \mathrm{x}\right.$ g at $4^{\circ} \mathrm{C}$ for $5 \mathrm{~min}$ ), resuspended in cold PBS and stained according to the instructions of the cell cycle detection kit (cat. no. KGA512; KeyGen Biotech Co., Ltd.). Following incubation at $37^{\circ} \mathrm{C}$ for $30 \mathrm{~min}$, bovine pancreatic RNasewas added at a final concentration of $2 \mathrm{mg} / \mathrm{ml}$ with $20 \mathrm{mg} / \mathrm{ml}$ propidium iodide for $20 \mathrm{~min}$ at room temperature. A total of $2 \times 10^{4}$ cells were analyzed using a BD FACS Canto flow cytometer (Becton, Dickinson and Company). The data was analyzed using GraphPad Prism 7 (GraphPad Software, Inc.).

Protein expression analysis. The adherent cell lines were collected in radio immunoprecipitation assay (RIPA; cat. no. P0013B; Beyotime Institute of Biotechnology) buffer using a cell scraper and protein expression was analyzed using western blot analysis. A protein BCA assay kit (cat. no. 23227; Thermo Fisher Scientific, Inc.) was used to quantify the protein concentration. The samples $(50 \mu \mathrm{g})$ were separated using $10 \%$ SDS-PAGE and the proteins were transferred to PVDF membranes, then blocked with 5\% Blotting-Grade Blocker solution (cat. no. 180-6404; Bio-Rad Laboratories, Inc.). Subsequently, the membranes were incubated with the primary antibodies (diluted 1:1,000) overnight at $4^{\circ} \mathrm{C}$, washed 3 times with TBS containing $1 \%$ Tween-20, then incubated with the secondary antibodies (diluted 1:1,000) for $2 \mathrm{~h}$ at $37^{\circ} \mathrm{C}$. Finally, chemiluminescence reagents (cat. no. WBKLS0500; EMD Millipore) were used to visualize the target proteins and densitometry was analyzed using Image J v1 (National Institutes of Health.). GADPH or $\beta$-actin served as the loading control.

TUNEL assay. The cells were seeded in 6-well plates, containing glass coverslips and treated with delphinidin, then fixed with $4 \%$ paraformaldehyde for $20 \mathrm{~min}$ and permeabilized with $1 \mathrm{X}$ PBS $+0.1 \%$ Triton for 2 min both at $4^{\circ} \mathrm{C}$. TUNEL staining was performed using the Dead End Fluorometric TUNEL system in accordance with the manufacturer's instructions (cat. no. G3250; Promega Corporation). A total of $50 \mu 1$ TUNEL detection solution was added to the sample, then incubated for $60 \mathrm{~min}$ at $37^{\circ} \mathrm{C}$ in the dark. Subsequently, $10 \mu 1$ DAPI was added to the samples and incubated at room temperature for $5 \mathrm{~min}$. The samples were observed and recorded using a fluorescence microscope (IX71; Olympus Corporation) at a x200 magnification, from at least 5 fields of views for each sample. Then, ImageJ v1 (National Institutes of Health) to record TUNEL-positive cells. The nuclei stained with bright green fluorescence were considered to be TUNEL-positive cells.

Mitochondrial membrane potential assay. Approximately $2 \times 10^{5}$ cells were seeded in 6 -well plates and treated with 

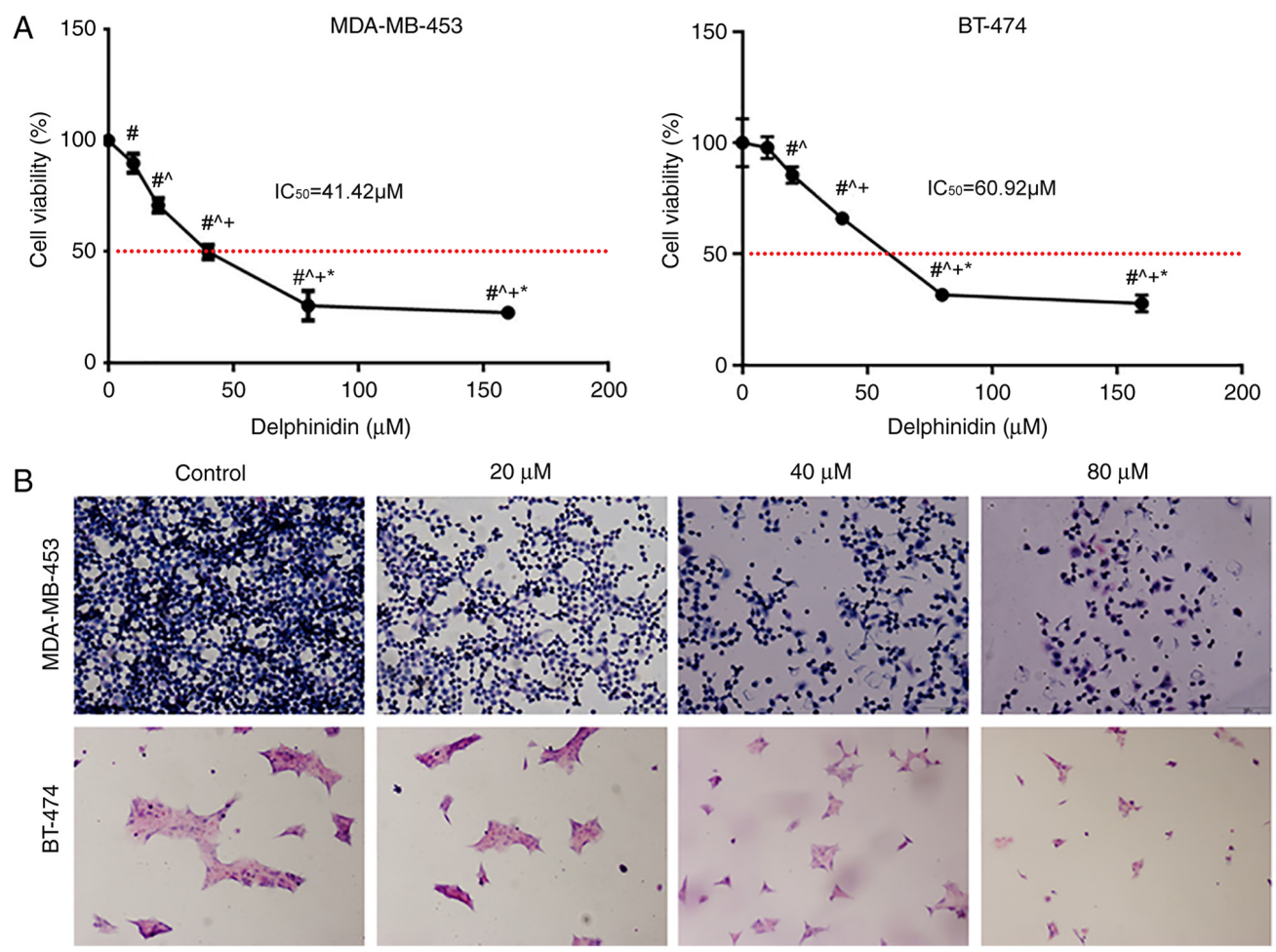

Figure 1. Delphinidin inhibits the viability of the epidermal growth factor receptor-2-positive breast cancer cell lines. (A) MDA-MB-453 and BT-474 cells were treated with 10,20, 40 or $80 \mu \mathrm{M}$ delphinidin or DMSO. Relative cell numbers were determined using a Cell Counting Kit- 8 assay after $48 \mathrm{~h} .{ }^{*} \mathrm{P}<0.05$ vs. control; ${ }^{\wedge} \mathrm{P}<0.05$ vs. $20 \mu \mathrm{M}$; ${ }^{+} \mathrm{P}<0.05$ vs. $40 \mu \mathrm{M}$; ${ }^{*} \mathrm{P}<0.05$ vs. $80 \mu \mathrm{M}$. (B) The MDA-MB-453 and BT- 474 cell lines were treated with 20,40 and $80 \mu \mathrm{M}$ delphinidin or DMSO. After $48 \mathrm{~h}$, the cells were fixed, stained with H\&E, then analyzed using a microscope (magnification, x200). Experiments were repeated at least 3 times. DMSO, dimethyl sulfoxide.

delphinidin at different concentrations $(20,40$ and $80 \mu \mathrm{M})$ or treated with DMSO for $8 \mathrm{~h}$. The cells were washed twice with PBS and incubated with L-15 or RPMI-1640 medium containing $10 \mu \mathrm{g}$ fluorescent lipophilic cationic JC-10 (cat. no. KGA608; Nanjing KeyGen Biotech Co., Ltd.) dye for $30 \mathrm{~min}$ at $37^{\circ} \mathrm{C}$ in the dark. The stained cells were harvested, washed and resuspended with PBS, then analyzed using a BD FACS Canto II flow cytometer and BD FACS Canto clinical software v2.4 (Becton, Dickinson and Company, Inc.) immediately. The lower-right quadrants represent cells with low membrane potential, while the upper-right quadrants represent cells with high membrane potential.

Detection of apoptosis using flow cytometry. An Annexin V-FITC Apoptosis Detection kit (cat. no. KGA108; Nanjing KeyGen Biotech Co., Ltd.) was used to detect apoptosis, as previously described (14). Annexin $\mathrm{V}^{+} / \mathrm{PI}^{-}$cells were considered early apoptotic and Annexin $\mathrm{V}^{+} / \mathrm{PI}^{+}$cells were considered late apoptotic. Double-negative cells (lower-left quadrant) were considered to be live cells. Annexin $\mathrm{V}^{-} \mathrm{PI}^{+}$cells (upper-left quadrant) were considered to be necrotic cells.

Immunofluorescence. Approximately $2 \times 10^{5}$ cells were seeded in 6-well plates, containing glass coverslips and treated with delphinidin at different concentrations $(20,40$ and $80 \mu \mathrm{M})$ or treated with DMSO for $48 \mathrm{~h}$, then fixed with $4 \%$ paraformaldehyde for $20 \mathrm{~min}$ at room temperature and permeabilized with $1 \mathrm{X}$ PBS $+0.5 \%$ Triton for $30 \mathrm{~min}$ at room temperature. The slides were blocked with PBS + 10\% FBS (cat. no. ES-009-B; EMD Millipore) and incubated with anti-NF-kB/p65 (diluted
1:200) in PBS for $12 \mathrm{~h}$ at $4^{\circ} \mathrm{C}$, then washed twice with PBS, and incubated with the Alexa Fluor 594-conjugated secondary antibody (diluted 1:500) for $2 \mathrm{~h}$ at room temperature. Following which, the slides were washed twice with PBS and mounted with Prolong Gold with Alexa Fluor 488 Phalloidin (diluted 1:20) and DAPI (cat. no. C0065; Beijing Solarbio Science and Technology Co., Ltd.). Finally, the images were captured using a confocal microscope (magnification, x600; FV1200; Olympus, Corporation). The results were determined using ImageJ software v.1 (National Institutes of Health) (15).

Statistical analysis. All the data are presented as the mean \pm standard error of the mean, and each experiment was performed at least three times. The statistical analyses were performed using one-way ANOVA and the Tukey's post hoc test using SPSS version 21.0 (IBM Corp.). $\mathrm{P}<0.05$ was considered to indicate a statistically significant difference. GraphPad Prism 7 (GraphPad software, Inc.) was used to generate the figures.

\section{Results}

Delphinidin inhibits the viability of the MDA-MB-453 and $B T-474$ breast cancer cell lines. To understand the effects of delphinidin on the breast cancer cell lines, the inhibitory effect of delphinidin on the viability of the HER-2-positive MDA-MB-453 and BT-474 breast cancer cell lines was analyzed (Fig. 1A). Delphinidin inhibited the viability of the HER-2-positive MDA-MB-453 and BT-474 breast cancer cell lines in a dose-dependent manner, with $\mathrm{IC}_{50}$ values of 

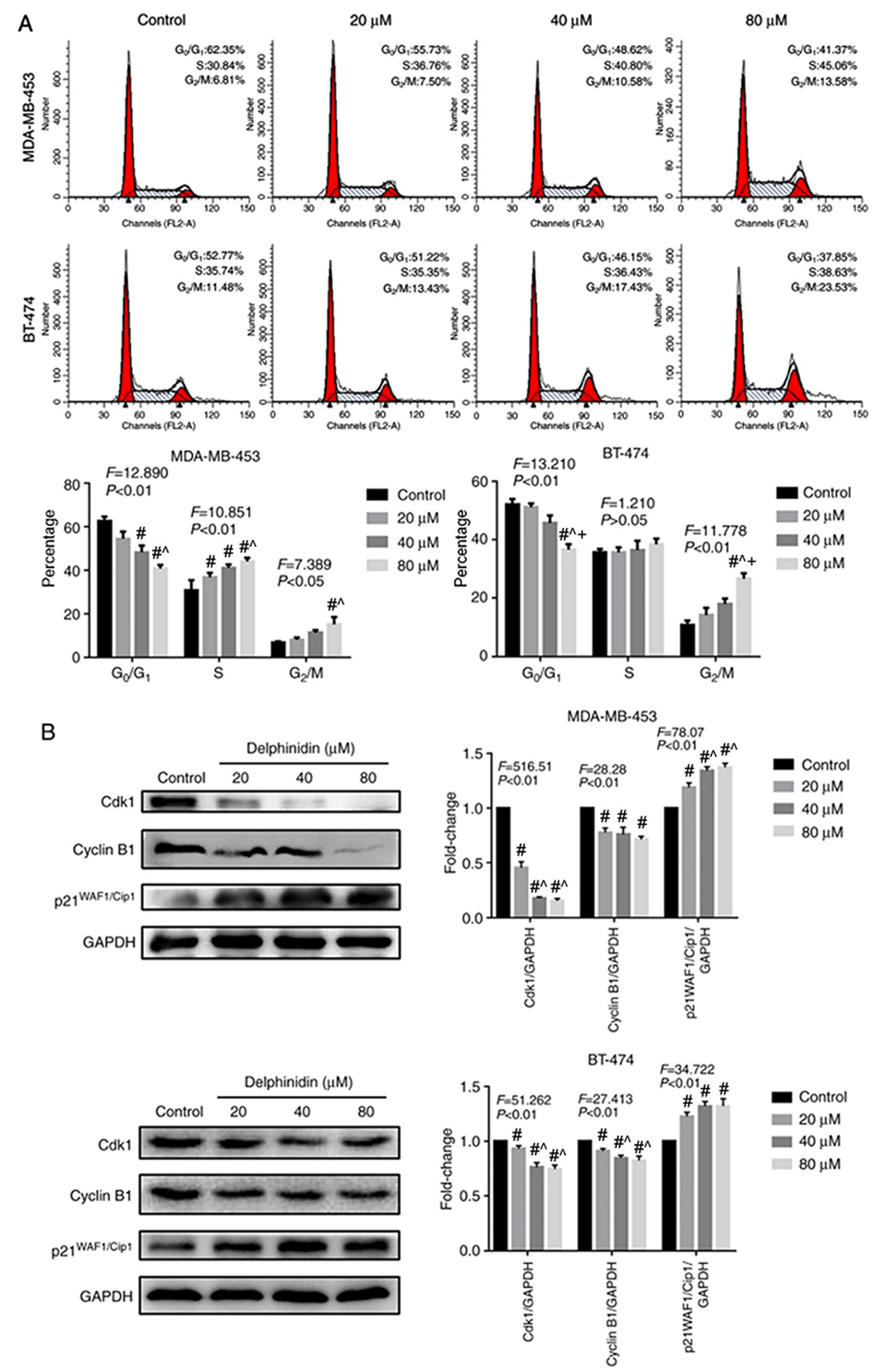

Figure 2. Effect of delphinidin on the cell cycle in the epidermal growth factor receptor-2-positive breast cancer cell lines. The MDA-MB-453 and BT-474 cells were treated with 20,40 and $80 \mu \mathrm{M}$ delphinidin or dimethyl sulfoxide for $48 \mathrm{~h}$. (A) Analysis of the cell cycle using flow cytometry following staining with PI. $\mathrm{n}=3$. (B) Cyclin B1, Cdk2 and p21 ${ }^{\text {WAF1/Cipl }}$ protein expression levels in the MDA-MB-453 and BT-474 cell lines were analyzed using western blot analysis and analyzed using ImageJ. GADPH served as the loading control. The data are presented as the mean \pm standard error of the mean from at least 3 independent experiments. ${ }^{~} \mathrm{P}<0.05$ vs. control; ${ }^{\wedge} \mathrm{P}<0.05$ vs. $20 \mu \mathrm{M} ;{ }^{+} \mathrm{P}<0.05$ vs. $40 \mu \mathrm{M}$.

41.42 and $60.92 \mu \mathrm{M}$, respectively (Fig. 1A). Therefore, 20, 40 and $80 \mu \mathrm{M}$ concentrations of delphinidin were used in subsequent experiments.

Following treatment of the cells with different concentrations of delphinidin and staining of the cells with H\&E, some of the cells detached and floated, prior to fixation, and the cell volume gradually decreased as the concentration of delphinidin increased (Fig. 1B).
Delphinidin promotes cell cycle progression in the MDA-MB-453 and BT-474 breast cancer cell lines. To determine whether delphinidin could affect cell cycle regulation in the MDA-MB-453 and BT-474 breast cancer cell lines, the effect of delphinidin on $\mathrm{G}_{2} / \mathrm{M}$ phase distribution was analyzed using flow cytometry, following staining with PI. As shown in Fig. 2A, delphinidin treatment significantly inhibited $\mathrm{G}_{2} / \mathrm{M}$ phase arrest in the HER-2-positive breast cancer cell lines. 
Further analysis revealed that the distribution of the cells in $\mathrm{G}_{2} / \mathrm{M}$ phase was $7.5,10.58$ and $13.58 \%$ in the MDA-MB-453 breast cancer cell line with 20,40 and $80 \mu \mathrm{M}$ delphinidin, respectively. The distribution of cells in the $\mathrm{G}_{2} / \mathrm{M}$ phase was $13.43,17.43$ and $23.53 \%$ in the BT-474 breast cancer cell line with 20, 40 and $80 \mu \mathrm{M}$ delphinidin, respectively.

As delphinidin inhibited $\mathrm{G}_{2} / \mathrm{M}$ phase progression, the protein expression levels of key cell cycle regulators were analyzed in the MDA-MB-453 and BT-474 breast cancer cell lines using western blot analysis (Fig. 2B). The results demonstrated that in the MDA-MB-453 and BT-474 breast cancer cell lines, 20, 40 and $80 \mu \mathrm{M}$ delphinidin significantly reduced the protein expression level of cyclin $\mathrm{B} 1$ and $\mathrm{cdk} 2$, and increased the protein expression level of $\mathrm{p} 21^{\mathrm{WAF} 1 / \mathrm{Cip} 1}$ following treatment for $48 \mathrm{~h}$.

Delphinidin induces apoptosis in the MDA-MB-453 and BT-474 breast cancer cell lines. The aforementioned experiments confirmed that delphinidin could induce $\mathrm{G}_{2} / \mathrm{M}$ phase cell cycle arrest in the MDA-MB-453 and BT-474 breast cancer cell lines. To determine whether cell cycle changes could lead to apoptosis and whether delphinidin inhibited the proliferation of the breast cancer cell lines, TUNEL staining was performed. The DNA fragment levels in the MDA-MB-453 and BT-474 breast cancer cell lines notably increased following delphinidin treatment, due to increase in fluorescent staining, and the number of dead cells increased with increasing concentrations of delphinidin, compared with that in the control group $(\mathrm{P}<0.05$; Fig. $3 \mathrm{~A})$. As shown in Fig. $3 \mathrm{~A}$ and $\mathrm{B}$, concentrations of 20,40 and $80 \mu \mathrm{M}$ delphinidin resulted in apoptosis rates of 3.3, 5.4 and $20.2 \%$ in the MDA-MB-453 cell line, respectively. Apoptosis rates reached and 1.4, 4.4 and $7.9 \%$ in the BT-474 breast cancer cell line following treatment with 20, 40 and $80 \mu \mathrm{M}$ delphinidin, respectively.

Mitochondria are producers of ATP, and their transmembrane potential is formed by the displacement of the transmembrane protons in the process of ATP generation (16). A previous study has shown that irreversible apoptosis occurs in breast cancer cell lines with very low mitochondrial membrane potential (17). Flow cytometry results showed that the mitochondrial membrane potential of the MDA-MB-453 and BT-474 breast cancer cell lines decreased with increasing concentrations of delphinidin compared with that in the control group (UR and UL quadrants; Fig. 3C). At concentrations of 40 and $80 \mu \mathrm{M}$ delphinidin, the apoptosis rate of the MDA-MB-453 cells was 49.58 and $53.87 \%$, and those of the BT-474 cells was 17.55 and $55.18 \%$, respectively (Fig. 3D). These results demonstrated that delphinidin could induce apoptosis in MDA-MB-453 and BT-474 breast cancer cell lines.

Delphinidin induces mitochondrial pathway apoptosis by inhibiting the ERK signaling pathway and activating the JNK signaling pathway. To determine whether the MAPK pathway played a role in mediating the effects of delphinidin, the expression levels of the Bcl-2 protein family were analyzed, as well as proteins in the MAPK signaling pathway, such as c-Raf, MEK1/2, ERK1/2, JNK, p-c-Raf, p-MEK1/2, p-ERK1/2 and p-JNK in the BT-474 and MDA-MB-453 breast cancer cell lines. The protein expression levels of Bax and Bcl-2 was increased and decreased, respectively with increasing concentrations of delphinidin in the MDA-MB-453 and BT-474 cell lines $(\mathrm{P}<0.05$; Fig. 4A and $\mathrm{B})$. In addition, compared with that in the control group, the ratio of $\mathrm{Bcl}-2 / \mathrm{Bax}$ decreased significantly in the 40 and $80 \mu \mathrm{M}$ delphinidin treatment group $(\mathrm{P}<0.05)$. Furthermore, the protein expression levels of p-c-Raf, p-MEK1/2 and p-ERK1/2 decreased, and the protein expression level of p-JNK increased, in the MDA-MB-453 and BT-474 cell lines, indicating that delphinidin induced mitochondrial pathway apoptosis by inhibiting ERK signaling and activating JNK signaling in the HER-2-positive breast cancer cell lines (Fig. 4C and D).

Delphinidin induces apoptosis by inhibiting the $N F-\kappa B$ signaling pathway in the HER-2-positive breast cancer cell lines. A previous study suggested that anthocyanins could induce apoptosis in various cancer cell lines, including stomach, prostate, intestine and breast cancer, by blocking the $\mathrm{NF}-\kappa \mathrm{B}$ signaling pathway (18). To investigate whether delphinidin reduced the viability of the HER-2-positive breast cancer cell lines by inhibiting $\mathrm{NF}-\kappa \mathrm{B}$ signaling, the protein expression levels of NF- $\kappa \mathrm{B}$ signaling-related molecules in the MDA-MB-453 and BT-474 breast cancer cell lines were analyzed. Compared with that in the control group, the protein expression levels of $\mathrm{p}-\mathrm{NF}-\kappa \mathrm{B} / \mathrm{P} 65, \mathrm{p}-\mathrm{IKK} \alpha / \beta$ and $\mathrm{p}-\mathrm{PKC} \alpha$ decreased significantly in the MDA-MB-453 and BT-474 high-concentration (40 and $80 \mu \mathrm{M}$ ) delphinidin treatment groups. In addition, the protein expression level of I $\mathrm{B} \mathrm{B} \alpha$, IKK $\alpha$, IKK $\beta$ and PKC $\alpha$ increased following delphinidin treatment (Fig. 5). The results suggested that delphinidin could block $N F-\kappa B$ signaling in the MDA-MB-453 and BT-474 breast cancer cell lines by inhibiting $\mathrm{NF}-\kappa \mathrm{B} / \mathrm{P} 65, \mathrm{I} \kappa \mathrm{B} \alpha$, and IKK $\alpha / \beta$ activity.

Immunofluorescence was used to detect the effect of delphinidin on nuclear translocation of $\mathrm{NF}-\kappa \mathrm{B} / \mathrm{p} 65$ in the MDA-MB-453 and BT-474 breast cancer cell lines. The results showed that the levels of $\mathrm{NF}-\kappa \mathrm{B} / \mathrm{p} 65$ nuclear translocation decreased in the delphinidin-treated groups. Thus, delphinidin reduced NF- $\kappa \mathrm{B} / \mathrm{p} 65$ entry into the nucleus and inhibited transcription of nuclear genes (Fig. 6).

\section{Discussion}

Cancer is characterized by abnormal cell proliferation, cell cycle regulation and apoptosis (19). Lim et al $(20,21)$ confirmed that delphinidin could reduce the survival rate of ovarian and liver cancer cells in a dose-dependent manner, and could also significantly inhibit proliferation, migration and invasion in a SKOV3 ovarian cancer cell line. Venancio et al (22) demonstrated that anthocyanins played an anti-inflammatory and anti-proliferating role by inhibiting the protein expression level of inflammatory cytokines, TNF- $\alpha$, IL-1 $\beta$ and IL-6 in colonic inflammatory fibroblasts and colon cancer cells. In the present study, it was found that delphinidin inhibited the viability of HER-2-positive MDA-MB-453 and BT-474 breast cancer cell lines and this inhibitory effect increased with delphinidin concentration.

Previous studies have demonstrated that anthocyanidin could induce $\mathrm{G}_{2} / \mathrm{M}$ cell cycle arrest by increasing the phosphorylation of Cdk1 at Tyr15 and increasing the protein expression level of Cdk inhibitors, p2 $7^{\mathrm{kip} 1}$ and $\mathrm{p} 21^{\mathrm{WAF} 1 / \mathrm{Cip} 1}$ in 

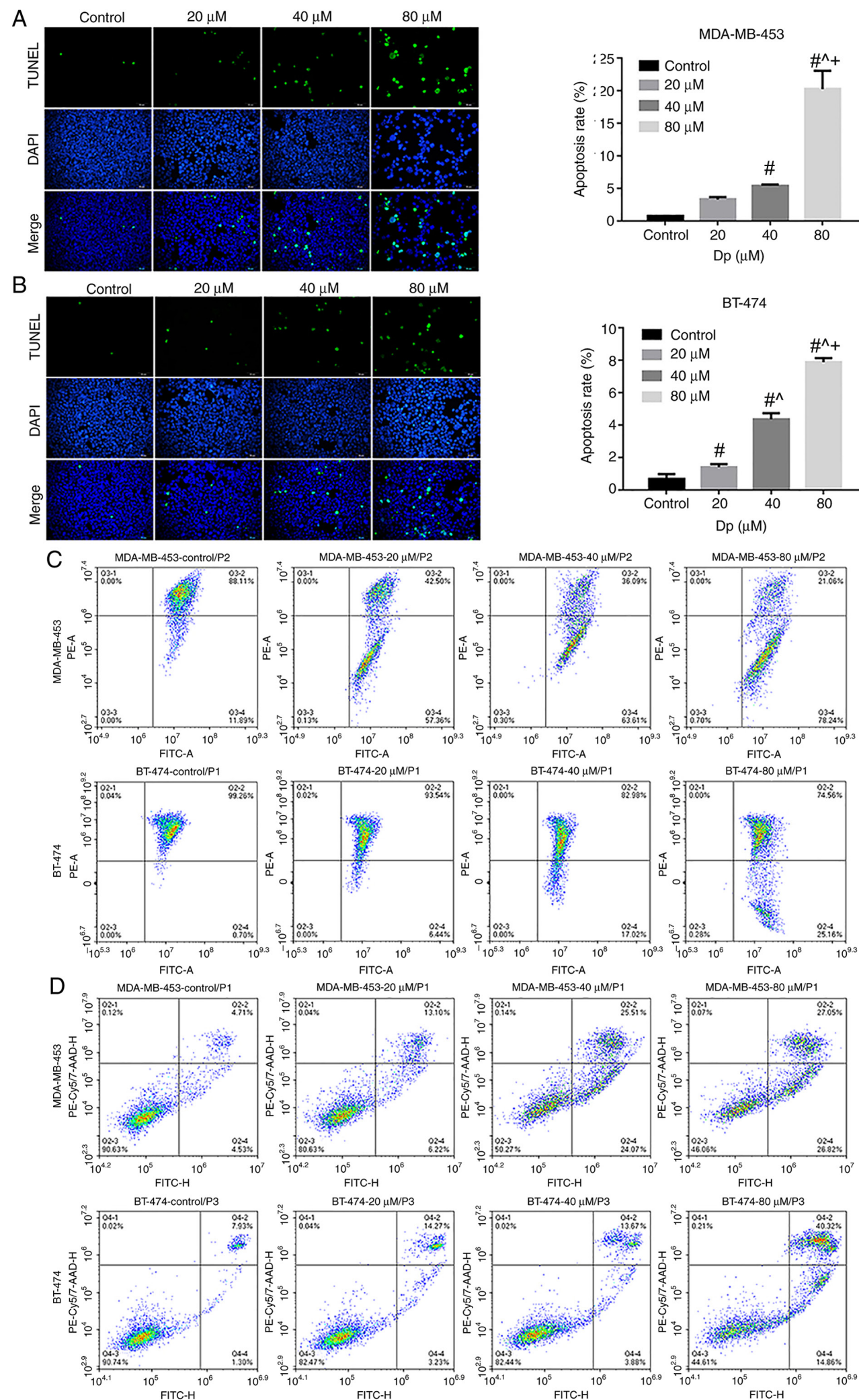

Figure 3. Delphinidin induces apoptosis in the MDA-MB-453 and BT-474 cell lines. The cells were treated with $0,20,40$ or $80 \mu \mathrm{M}$ delphinidin or dimethyl sulfoxide for $48 \mathrm{~h}$. Representative images of TUNEL-positive (A) MDA-MB-453 and (B) BT-474 cell lines and the data was statistically analyzed. The cells were treated with $0,20,40$ or $80 \mu \mathrm{M}$ delphinidin for $8 \mathrm{~h}$. (C) Mitochondrial membrane potential was analyzed using flow cytometry. (D) Apoptosis was analyzed using flow cytometry. Magnification, $\mathrm{x} 200 . \mathrm{n}=3$. ${ }^{\#} \mathrm{P}<0.05$ vs. control; ${ }^{\wedge} \mathrm{P}<0.05$ vs. $20 \mu \mathrm{M} ;{ }^{+} \mathrm{P}<0.05$ vs. $40 \mu \mathrm{M}$.

leukemia cell lines $(23,24)$. Clemente-Soto et al $(25)$ found that quercetin induced the protein expression level of $\mathrm{p} 21^{\mathrm{WAF} 1 / \mathrm{Cip} 1}$ by activating p53 and induced apoptosis in the HeLa and $\mathrm{SiHa}$ cell lines. In the present study, it was demonstrated that delphinidin could induce $\mathrm{G}_{2} / \mathrm{M}$ cell cycle arrest in the HER-2-positive MDA-MB-453 and BT-474 breast cancer cell lines and that the $\mathrm{G}_{2} / \mathrm{M}$ cell cycle arrest was associated with the inhibition of multiple key cell cycle regulators, such as Cdk1 
A

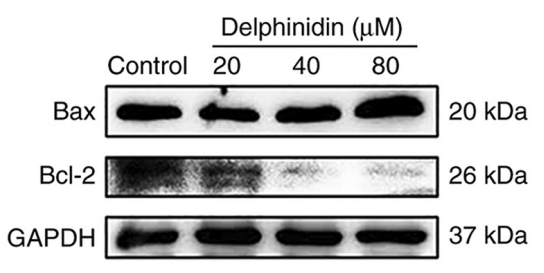

B

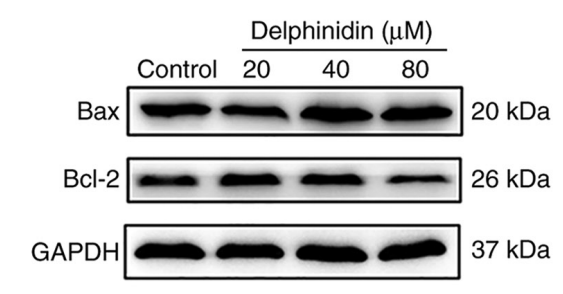

C

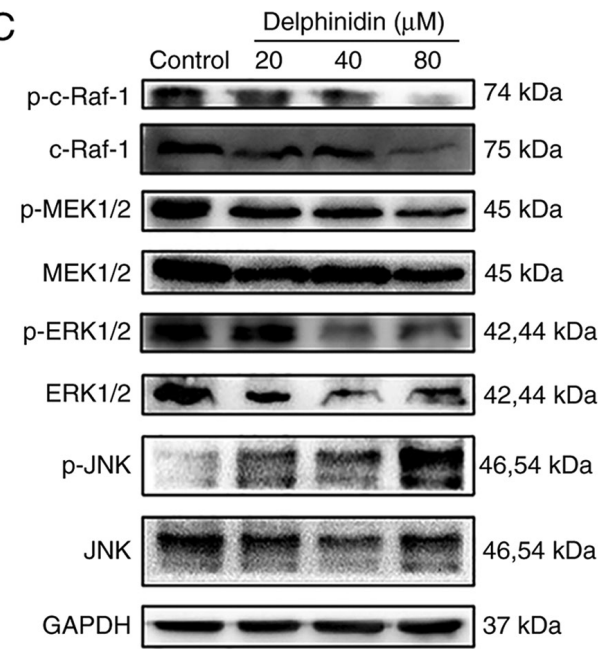

D

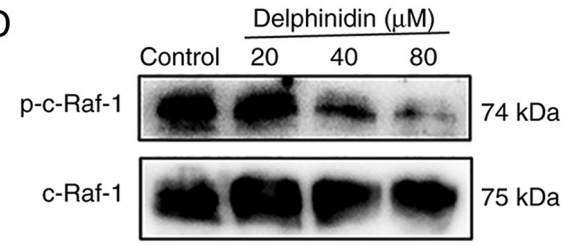

P-MEK $1 / 2 \rightleftharpoons 45 \mathrm{kDa}$

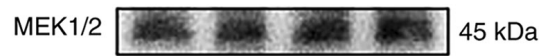

p-ERK $1 / 2 \square 42,44 \mathrm{kDa}$

ERK $1 / 2 \longrightarrow 42,44 \mathrm{kDa}$

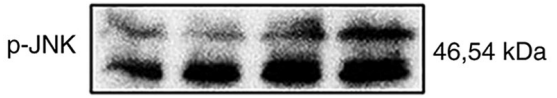

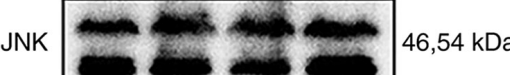

GAPDH $37 \mathrm{kDa}$
MDA-MB-453

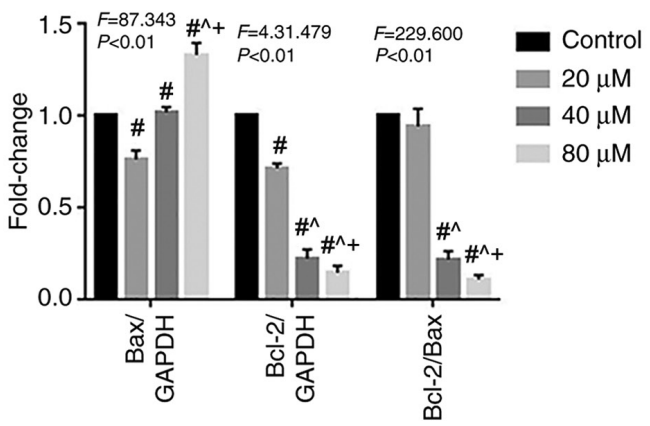

BT-474
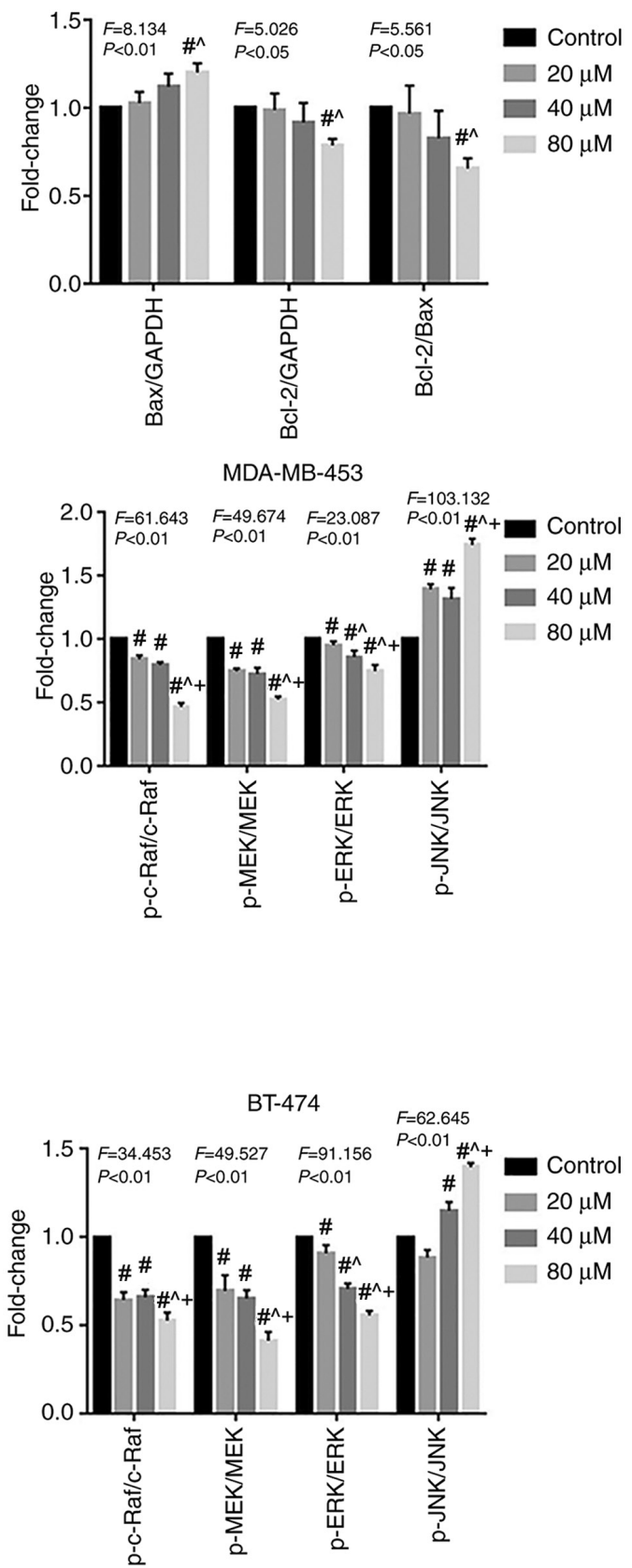

Figure 4. Effect of delphinidin on the cell cycle in the epidermal growth factor receptor-2-positive breast cancer cell lines. The MDA-MB-453 and BT-474 cells were treated with 20,40 and $80 \mu \mathrm{M}$ delphinidin or dimethyl sulfoxide for $48 \mathrm{~h}$. Bcl-2 protein expression level and proteins in the MAPK signaling pathway in the (A and C) MDA-MB-453 and (B and D) BT-474 cell lines, respectively were analyzed using western blot analysis and densitometry. The data are presented as the mean and SD from at least 3 independent experiments. ${ }^{~} \mathrm{P}<0.05$ vs. control; ${ }^{\wedge} \mathrm{P}<0.05$ vs. $20 \mu \mathrm{M}$; ${ }^{+} \mathrm{P}<0.05$ vs. $40 \mu \mathrm{M}$. p, phosphorylated. 
A

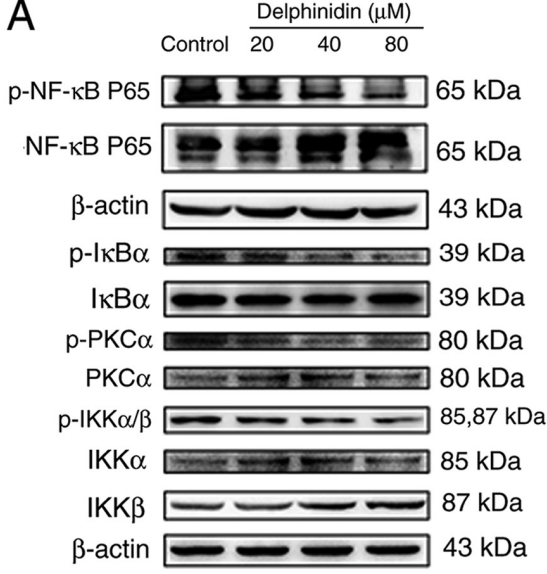

B

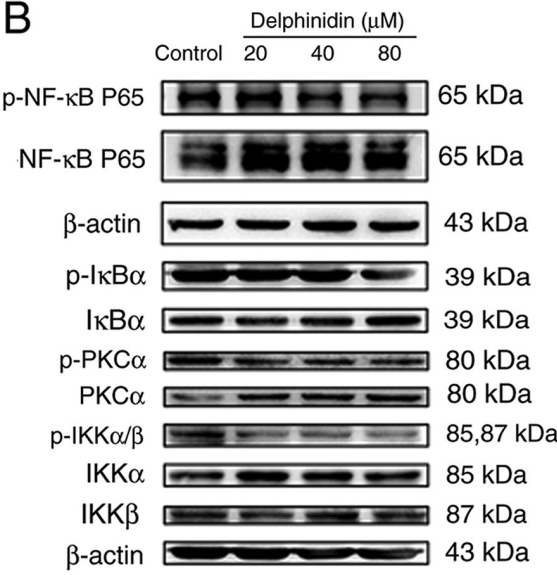

MDA-MB-453

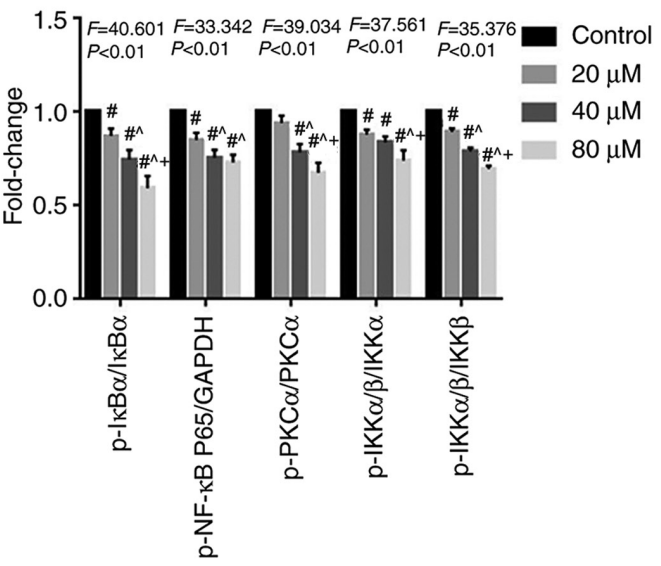

BT-474

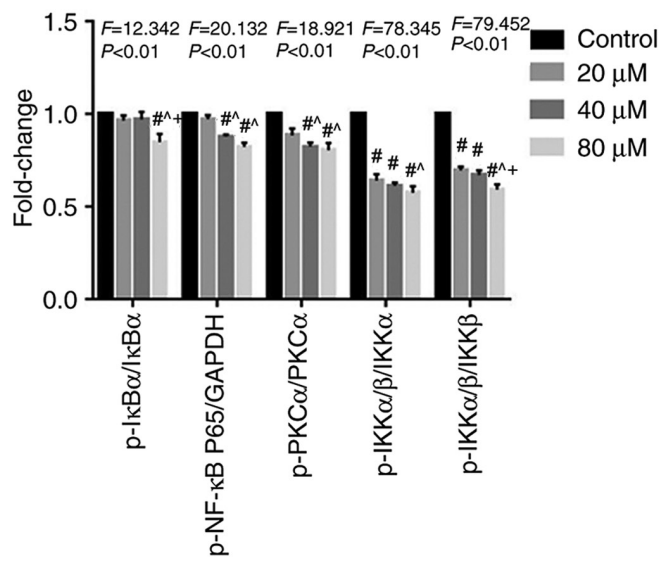

Figure 5. Delphinidin induces epidermal growth factor receptor-2-positive breast cancer cell apoptosis by blocking the NF- $\kappa \mathrm{B}$ signaling pathway. After treatment with delphinidin for $48 \mathrm{~h}$, total protein expression and phosphorylation of NF- $\kappa \mathrm{B} / \mathrm{p} 65$, I $\mathrm{B} \alpha$, IKK $\alpha / \beta$ and PKC $\alpha$ were detected using western blot analysis . Phosphorylation of proteins in the NF- $\mathrm{BB}$ pathway in (A) MDA-MB-453 and (B) BT-474 cell lines. p, phosphorylated. The data are presented as the mean and $\mathrm{SD}$ from at least 3 independent experiments. ${ }^{\#} \mathrm{P}<0.05$ vs. control; ${ }^{\wedge} \mathrm{P}<0.05$ vs. $20 \mu \mathrm{M} ;{ }^{+} \mathrm{P}<0.05$ vs. $40 \mu \mathrm{M}$.

and cyclin B1. It can be hypothesized that delphinidin induced $\mathrm{G}_{2} / \mathrm{M}$ phase arrest by increasing the protein expression level of $\mathrm{p} 21^{\mathrm{WAF} 1 / \mathrm{Cip} 1}$, and may be involved in the induction of apoptosis in MDA-MB-453 and BT-474 breast cancer cell lines.

Loss of normal regulation of apoptosis is an important reason for the dysregulated proliferation of cancer cells $(19,25,26)$. Induction of apoptosis may represent an effective way to treat malignant tumors. A previous study suggested that cytarabine, nitrogen mustard, cisplatin and topological isoenzyme inhibitors can induce apoptosis (27). There are 3 types of apoptotic pathways: The death receptor pathway, the mitochondrial apoptosis pathway and the endoplasmic reticulum apoptosis pathway. During the process of apoptosis, these 3 pathways may be initiated simultaneously or separately.

Kang et al (28) found that delphinidin inhibited the ERK/p38 MAPK signaling pathway by decreasing the phosphorylation levels of ERK and p38, and exerted anti-proliferative and pro-apoptotic effects in human osteosarcoma cells. Delphinidin inhibited the proliferation of ES2 and SKOV3 ovarian cancer cells by inhibiting the PI3K/AKT and ERK signaling pathways $(29,30)$, which is consistent with the results of the present study. Several studies have also suggested that JNK could play an important role in cell cycle regulation, while JNK inhibited Cdk1 activation and caused $\mathrm{G}_{2} / \mathrm{M}$ phase arrest $(31,32)$. Activated JNK stabilized the activity of $\mathrm{p} 21^{\mathrm{WAF} 1 / \mathrm{Cip} 1}$ by post-translational protein modification $(32,33)$. In the present study, it was found that different concentrations of delphinidin significantly decreased the protein expression levels of p-c-Raf, p-MEK1/2 and p-ERK1/2, and increased the protein expression levels of p-JNK in the MDA-MB-453 and BT-474 breast cancer cell lines. It could be hypothesized that delphinidin-induced apoptosis may be associated with the ERK and JNK signaling pathway in the HER-2-positive breast cancer cell lines. The present study also found that delphinidin increased the protein expression level of p21 ${ }^{\mathrm{WAF} 1 / \mathrm{Cip} 1}$, while inducing $\mathrm{G}_{2} / \mathrm{M}$ phase arrest in the HER-2-positive breast cancer cells, which may be associated with the activation of the JNK signaling pathway.

The NF- $\mathrm{B}$ signaling pathway plays an important role in the survival and proliferation of tumor cells, as well as inflammation, apoptosis. In the steady state, $\mathrm{NF}-\kappa \mathrm{B}$ is bound to its inhibitor (IкB) and remains inactive $(32,33)$. Numerous extracellular stimulating factors, such as TNF- $\alpha$, IL-1, lipopolysaccharide (LPS) and other chemicals or physical stressors (such as ultraviolet light), can phosphorylate IKB causing its degradation $(32,33)$. The dissociated NF-KB then translocates to the nucleus and exposes nuclear recognition sites, thereby participating in target gene transcription $(34,35)$. Previous studies have shown that 
A

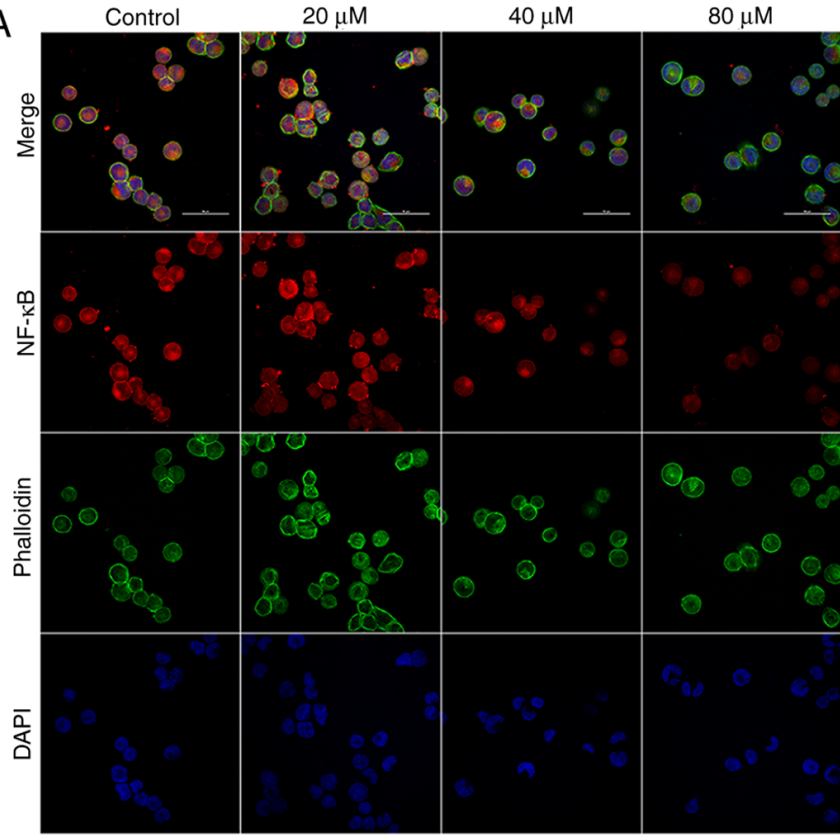

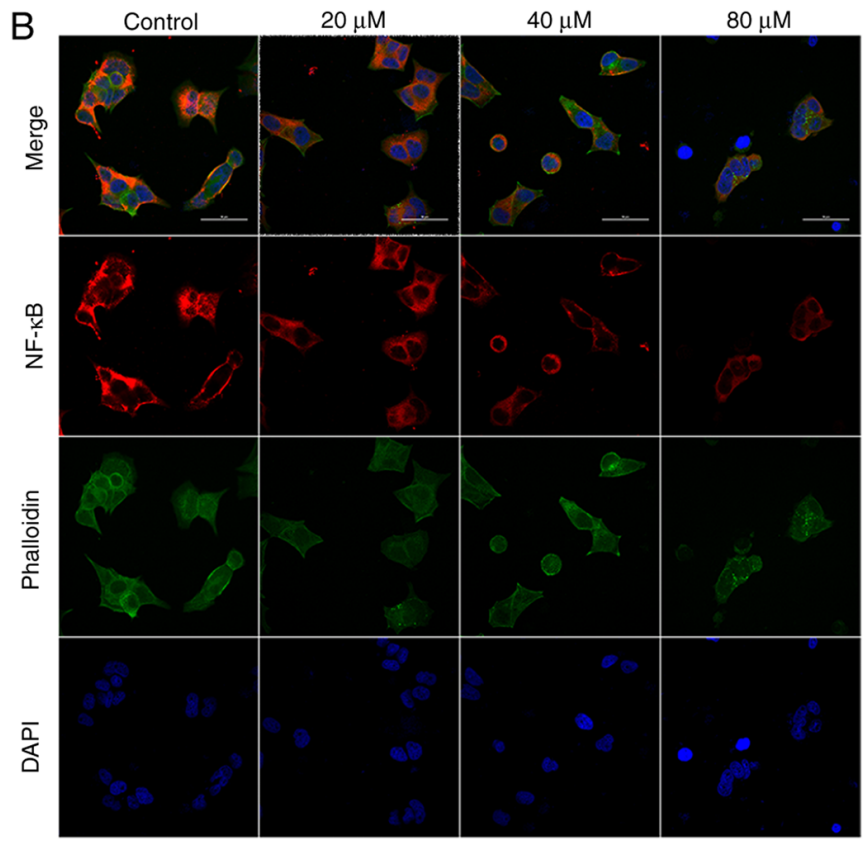

Figure 6. Delphinidin inhibits NF- $\mathrm{BB} / \mathrm{p} 65$ nuclear translocation in epidermal growth factor receptor-2-positive breast cancer cell lines. MDA-MB-453 and BT-474 cells were treated with different concentrations of delphinidin for $48 \mathrm{~h}$ and intracellular NF- $\mathrm{kB}$ nuclear translocation was detected using immunofluorescence and confocal microscopy. NF- $\kappa$ B/p65 nuclear localization in the (A) MDA-MB-453 and (B) BT-474 cell lines. Magnification x600.

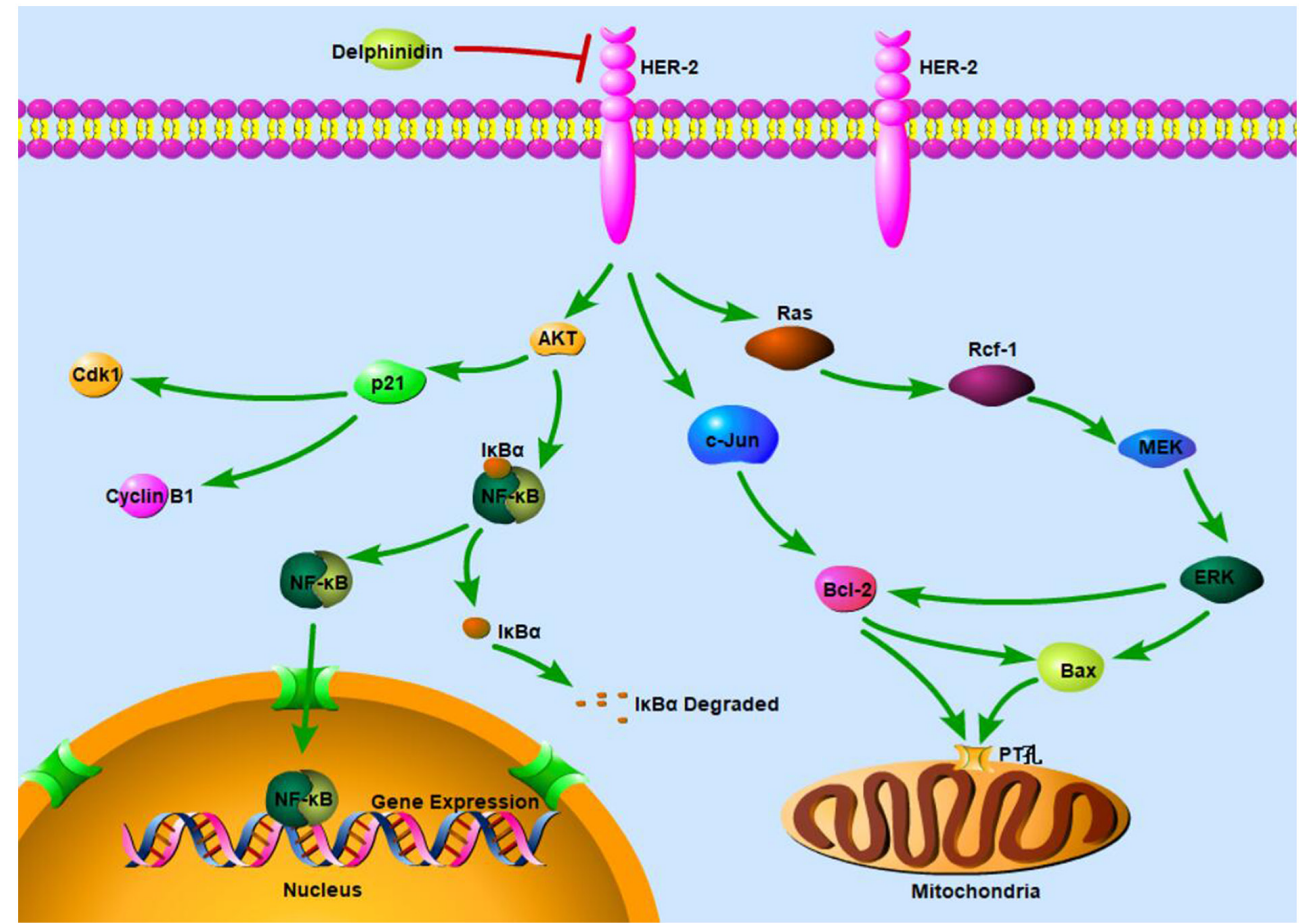

Figure 7. Schematic diagram of the molecular mechanism underlying inhibition of HER-2-positive breast cancer cell viability by delphinidin. HER, epidermal growth factor receptor.

NF-KB was abnormally activated in breast cancer cell lines. Luo et al (34) demonstrated that ursolic acid inhibited breast cancer growth by inhibiting proliferation, inducing apoptosis and suppressing inflammatory responses via NF-KB signaling in vitro. In addition, NF-KB could inhibit JNK-mediated apoptosis (36-38). Papa et al (38) showed that NF-KB could be inhibited during TNF- $\alpha$-induced apoptosis. It caused activation of JNK, which ultimately lead to JNK signaling pathway-mediated apoptosis. Lee et al (39) demonstrated that delphinidin inhibited LPS-induced macrophage NF-kB/p65 nuclear translocation. Haseeb et al (40) reported that delphinidin could inhibit IL-1 $\beta$-induced activation of NF- $\mathrm{KB} / \mathrm{p} 65$ in chondrocytes and blocked NF- $\mathrm{NB} / \mathrm{p} 65$ nuclear translocation. The present study found that the phosphorylation levels of NF- $\mathrm{kB} / \mathrm{p} 65$, IKK $\alpha / \beta$, 
PKC $\alpha$ significantly decreased in the MDA-MB-453 and BT-474 breast cancer cell lines following treatment with 40 and $80 \mu \mathrm{M}$ delphinidin. In addition, the nuclear translocation of NF- $\mathrm{kB} / \mathrm{p} 65$ decreased as the concentration of delphinium increased. These findings are consistent with a previous study (40) demonstrating that delphinidin inhibited the activation and nuclear translocation of NF- $\mathrm{kB} / \mathrm{p} 65$. Based on these results, it may be hypothesized that the antitumor activity of delphinidin was associated with the inhibition of the NF- $\mathrm{KB}$ signaling pathway and the activation of the JNK signaling pathway.

The BT-474 cells are a HER-2-positive cell line, therefore the conclusions made in the present study could be applied to all HER-2-positive breast cancer cell lines. However, the effect of delphinidin was only analyzed in HER-2-positive breast cancer cell lines; therefore, further investigation is required in different breast cancer cell lines.

In conclusion, the present study identified the molecular mechanism in which delphinidin inhibited the viability of the HER-2-positive breast cancer cell lines. Delphinidin inhibited the ERK signaling pathway by decreasing the protein expression level of p-c-Raf, p-MEK1/2 and p-ERK1/2, regulating the protein expression level of $\mathrm{Bax}$ and $\mathrm{Bcl}-2$ and reducing the proportion of $\mathrm{Bax} / \mathrm{Bcl}-2$ heterodimers, thereby mediating apoptosis in the mitochondrial pathway. Furthermore, delphinidin inhibited the activation of NF- $\mathrm{\kappa B}$ and nuclear translocation of NF- $\mathrm{kB} / \mathrm{p} 65$ by inhibiting the degradation of I $\kappa \mathrm{B}-\alpha$, blocking the NF- $\kappa \mathrm{B}$ signaling pathway and promoting the JNK signaling pathway, thereby inducing $\mathrm{G}_{2} / \mathrm{M}$ phase arrest and apoptosis (Fig. 7).

\section{Acknowledgements}

Not applicable.

\section{Funding}

This study was supported by the National Natural Science Foundation of China (grant nos. 81573154, 82073539 and 81773432).

\section{Availability of data and materials}

The datasets used and/or analyzed during the current study are available from the corresponding author on reasonable request.

\section{Authors' contributions}

$\mathrm{AW}, \mathrm{XY}, \mathrm{YZ}$ and $\mathrm{BH}$ confirm the authenticity of all the raw data. AW, YZ, WC, XP and XY designed the study. AW, JP, XD, JD, $\mathrm{YO}$ and $\mathrm{BH}$ conducted the research and analyzed the data. AW, $\mathrm{XP}, \mathrm{YZ}$ and $\mathrm{BH}$ wrote the manuscript with input from the other authors. All authors read and approved the final manuscript.

\section{Ethics approval and consent to participate}

Not applicable.

\section{Patient consent for publication}

Not applicable.

\section{Competing interests}

The authors declare that they have no competing interests.

\section{References}

1. Chan CW, Law BM, So WK, Chow KM and Waye MM: Novel strategies on personalized medicine for breast cancer treatment: An update. Int J Mol Sci 18: 2423, 2017.

2. Akram M, Iqbal M, Daniyal M and Khan AU: Awareness and current knowledge of breast cancer. Biol Res 50: 33, 2017.

3. Nami B, Maadi H and Wang Z: Mechanisms underlying the action and synergism of trastuzumab and pertuzumab in targeting HER2-positive breast cancer. Cancers (Basel) 10: 342, 2018.

4. Hafeez BB, Siddiqui IA, Asim M, Malik A, Afaq F, Adhami VM, Saleem M, Din M and Mukhtar H: A dietary anthocyanidin Delphinidin induces apoptosis of human prostate cancer PC3 cells in vitro and in vivo: Involvement of nuclear factor-kappaB signaling. Cancer Res 68: 8564-8572, 2008.

5. Jing P, Qian B, Zhao S, Qi X, Ye L, Mónica Giusti M and Wang X: Effect of glycosylation patterns of Chinese eggplant anthocyanins and other derivatives on antioxidant effectiveness in human colon cell lines. Food Chem 172: 183-189, 2015.

6. Eghbaliferiz S and Iranshahi M: Prooxidant activity of polyphenols, flavonoids, anthocyanins and carotenoids: Updated review of mechanisms and catalyzing metals. Phytother Res 30: 1379-1391, 2016.

7. Fang J: Classification of fruits based on anthocyanin types and relevance to their health effects. Nutrition 31: 1301-1306, 2015.

8. Luo LP, Han B, Yu XP, Chen XY, Zhou J, Chen W, Zhu YF, Peng XL, Zou Q and Li SY: Anti-metastasis activity of black rice anthocyanins against breast cancer: Analyses using an ErbB2 positive breast cancer cell line and tumoral xenograft model. Asian Pac J Cancer Prev 15: 6219-6225, 2014.

9. Chen XY, Zhou J, Luo LP, Han B, Li F, Chen JY, Zhu YF, Chen $\mathrm{W}$ and $\mathrm{Yu} X P$ : Black rice anthocyanins suppress metastasis of breast cancer cells by targeting RAS/RAF/MAPK pathway. Biomed Res Int 2015: 414250, 2015.

10. Yang $X$, Luo E, Liu X, Han B, Yu X and Peng $X$ : Delphinidin-3-glucoside suppresses breast carcinogenesis by inactivating the Akt/HOTAIR signaling pathway. BMC Cancer 16: 423, 2016.

11. Chen J, Zhu Y, Zhang W, Peng X, Zhou J, Li F, Han B, Liu X, Ou Y and Yu X: Delphinidin induced protective autophagy via mTOR pathway suppression and AMPK pathway activation in HER-2 positive breast cancer cells. BMC Cancer 18: 342, 2018.

12. Kang NJ, Lee KW, Kwon JY, Hwang MK, Rogozin EA, Heo YS, Bode AM, Lee HJ and Dong Z: Delphinidin attenuates neoplastic transformation in JB6 Cl41 mouse epidermal cells by blocking Raf/mitogen-activated protein kinase kinase/extracellular signal-regulated kinase signaling. Cancer Prev Res (Phila) 1: 522-531, 2008.

13. Yun JM, Afaq F, Khan N and Mukhtar H: Delphinidin, an anthocyanidin in pigmented fruits and vegetables, induces apoptosis and cell cycle arrest in human colon cancer HCT116 cells. Mol Carcinog 48: 260-270, 2009.

14. Chen S, Cheng AC, Wang MS and Peng X: Detection of apoptosis induced by new type gosling viral enteritis virus in vitro through fluorescein Annexin V-FITC/PI double labeling. World J Gastroenterol 14: 2174-2178, 2008.

15. Miao Y, Wang X, Lai Y, Lin W, Huang Y, Yin H, Hou R and Zhang F: Mitochondrial calcium uniporter promotes cell proliferation and migration in esophageal cancer. Oncol Lett 22, 2021.

16. Zorova LD, Popkov VA, Plotnikov EY, Silachev DN, Pevzner IB, Jankauskas SS, Babenko VA, Zorov SD, Balakireva AV, Juhaszova M, et al: Mitochondrial membrane potential. Anal Biochem 552: 50-59, 2018.

17. Cui L, Bu W, Song J, Feng L, Xu T, Liu D, Ding W, Wang J, Li C, Ma B, et al: Apoposis induction by alantolactone in breast cancer MDA-MB-231 cells through reactive oxygen species mediated mitochondrion dependent pathway. Arch Pharm Res 41: 299-313, 2018.

18. Boivin D, Blanchette M, Barrette S, Moghrabi A and Béliveau R: Inhibition of cancer cell proliferation and suppression of TNF induced activation of NFkappaB by edible berry juice. Anticancer Res 27: 937-948, 2007.

19. Ouyang L, Shi Z, Zhao S, Wang FT, Zhou TT, Liu B and Bao JK: Programmed cell death pathways in cancer: A review of apoptosis, autophagy and programmed necrosis. Cell Prolif 45: 487-498, 2012. 
20. Lim WC, Kim H and Ko H: Delphinidin inhibits epidermal growth factor-induced epithelial-to-mesenchymal transition in hepatocellular carcinoma cells. J Cell Biochem 120: 9887-9899, 2019.

21. Lim WC, Kim H, Kim YJ, Park SH, Song JH, Lee KH, Lee IH, Lee YK, So KA, Choi KC and Ko H: Delphinidin inhibits BDNF-induced migration and invasion in SKOV3 ovarian cancer cells. Bioorg Med Chem Lett 27: 5337-5343, 2017.

22. Venancio VP, Cipriano PA, Kim H, Antunes LM, Talcott ST and Mertens-Talcott SU: Cocoplum (Chrysobalanus icaco L.) anthocyanins exert anti-inflammatory activity in human colon cancer and non-malignant colon cells. Food Funct 8: 307-314, 2017.

23. Tsai TC, Huang HP, Chang KT, Wang CJ and Chang YC: Anthocyanins from roselle extract arrest cell cycle G2/M phase transition via ATM/Chk pathway in p53-deficient leukemia HL-60 cells. Environ Toxicol 32: 1290-1304, 2017.

24. El-Deiry WS: p21(WAF1) mediates cell-cycle inhibition, relevant to cancer suppression and therapy. Cancer Res 76: 5189-5191, 2016.

25. Clemente-Soto AF, Salas-Vidal E, Milan-Pacheco C, SánchezCarranza JN, Peralta-Zaragoza O and González-Maya L: Quercetin induces G2 phase arrest and apoptosis with the activation of p53 in an E6 expression in dependent manner in HPV positive human cervical cancer derived cells. Mol Med Rep 19: 2097-2106, 2019

26. Jiao Y, Wu Y and Du D: Polydatin inhibits cell proliferation, invasion and migration, and induces cell apoptosis in hepatocellular carcinoma. Braz J Med Biol Res 51: e6867, 2018

27. Liu L, Fan J, Ai G, Liu J, Luo N, Li C and Cheng Z: Berberine in combination with cisplatin induces necroptosis and ovarian cancer cells. Biol Res 52: 37, 2019.

28. Kang HM, Park BS, Kang HK, Park HR, Yu SB and Kim IR: Delphinidin induces apoptosis and inhibits epithelial-to-mesenchymal transition via the ERK/p38 MAPK-signaling pathway in human osteosarcoma cell lines. Environ Toxicol 33: 640-649, 2018.

29. Lim W and Song G: Inhibitory effects of Delphinidin on the proliferation of ovarian cancer cells via PI3K/AKT and ERK 1/2 MAPK signal transduction. Oncol Lett 14: 810-818, 2017.

30. Lim W, Jeong W and Song G: Delphinidin suppresses proliferation and migration of human ovarian clear cell carcinoma cells through blocking AKT and ERK1/2 MAPK signaling pathways. Mol Cell Endocrinol 422: 172-181, 2016.

31. Wu J, Sun J and Xue Y: Involvement of JNK and P53 activation in G2/M cell cycle arrest and apoptosis induced by titanium dioxide nanoparticles in neuron cells. Toxicol Lett 199: 269-276, 2010.
32. Zhu N, Shao Y, Xu L, Yu L and Sun L: Gadd45-alpha and Gadd45-gamma utilize p38 and JNK signaling pathways to induce cell cycle G2/M arrest in Hep-G2 hepatoma cells. Mol Biol Rep 36: 2075-2085, 2009.

33. Wang CC, Chiang YM, Sung SC, Hsu YL, Chang JK and Kuo PL: Plumbagin induces cell cycle arrest and apoptosis through reactive oxygen species/c-Jun N-terminal kinase pathways in human melanoma A375.S2 cells. Cancer Lett 259: 82-98, 2008.

34. Luo J, Hu YL and Wang H: Ursolic acid inhibits breast cancer growth by inhibiting proliferation, inducing autophagy and apoptosis, and suppressing inflammatory responses via the PI3K/AKT and NF- $\mathrm{KB}$ signaling pathways in vitro. Exp Ther Med 14: 3623-3631, 2017

35. Wang H, Huang W, Liang M, Shi Y, Zhang C, Li Q, Liu M, Shou Y, Yin H, Zhu X, et al: (+)-JQ1 attenuated LPS-induced microglial inflammation via MAPK/NFкB signaling. Cell Biosci 8: 60, 2018.

36. Bubici C, Papa S, Pham CG, Zazzeroni F and Franzoso G: NF-kappaB and JNK: An intricate affair. Cell Cycle 3: 1524-1529, 2004.

37. Sakon S, Xue X, Takekawa M, Sasazuki T, Okazaki T, Kojima Y, Piao JH, Yagita H, Okumura K, Doi T and Nakano H: NF-kappaB inhibits TNF-induced accumulation of ROS that mediate prolonged MAPK activation and necrotic cell death. EMBO J 22 3898-3909, 2003

38. Papa S, Zazzeroni F, Pham CG, Bubici C and Franzoso G: Linking JNK signaling to NF-kappaB: A key to survival. J Cell Sci 117: 5197-5208, 2004

39. Lee SG, Kim B, Yang Y, Pham TX, Park YK, Manatou J, Koo SI, Chun OK and Lee JY: Berry anthocyanins suppress the expression and secretion of proinflammatory mediators in macrophages by inhibiting nuclear translocation of $\mathrm{NF}-\kappa \mathrm{B}$ independent of NRF2-mediated mechanism. J Nutr Biochem 25: 404-411, 2014.

40. Haseeb A, Chen D and Haqqi TM: Delphinidin inhibits IL-1 $\beta$-induced activation of NF- $\mathrm{NB}$ by modulating the phosphorylation of IRAK-1(Ser376) in human articular chondrocytes. Rheumatology (Oxford) 52: 998-1008, 2013.

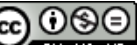

This work is licensed under a Creative Common Attribution-NonCommercial-NoDerivatives 4.0 International (CC BY-NC-ND 4.0) License. 